\title{
Study on Therapy for Depression with Four Kinds of Severities
}

\author{
Ziming Wang
}

\begin{abstract}
Depression was a common disease in our daily life, which was in urgent need of treatment. The pain that brought to patients was huge. According to WHO statistics, depression has become the fourth biggest hidden danger in the world. Therapy for depression with four kinds of severities was introduced concretely. The symptoms, therapeutic methods, therapeutic process and risk management and control of depression were studied systematically. It was applied including symptoms consultation and diagnosis, depression scale of testing and manipulating (WZM), physiological and chemical analysis of etiology for depression, antidepressant drugs selection and natural therapy for depression successfully The therapy was combined for depression in traditional Chinese and Western medicine. Therapy for depression was also applied to some patient. Thus curative effects were verified in each stage. The difficulties were discussed, which were encountered in the process of therapy for depression. So it was expected to be extended to a large number of depressed patients in order to improve therapeutic effects of depression and relieve the pain of patients.
\end{abstract}

Index Terms-Depression, four kinds of severities, antidepressant drugs, risk management and control.

\section{INTRODUCTION}

\section{A. Motivation and Aim}

Depression was usually considered as emotional disorders. Depression was a kind of syndrome, and the main feature was in low mood [1]. The classification of depression was diverse. And it could be divided into extremely severe, severe, moderate and mild according to the severity of the diseases.

According to WHO statistics, the number of people with depression was estimated to exceed 300 million people globally in 2015, which was equivalent to $4.4 \%$ of the global population. The number of people with depression was estimated to exceed 54 million people in China, which was equivalent to $4.2 \%$ of China's population. Heavy burden was brought to the patients themselves, the family and the society by depression. The number of people with suicide due to depression was estimated to nearly 800 thousand, which was equivalent to $1.5 \%$ of total mortality worldwide[2]. The diagnosis and therapy of traditional depression has reached a considerable maturity including Chinese medicine and Western medicine treatment, somatic therapy, sleep therapy, emotional therapy, cognitive therapy, phototherapy, acupuncture therapy, psychotherapy, natural therapy, alimentary therapeutic, cheiropractic, electroconvulsive therapy, magnet therapy and music

Manuscript received January 2, 2018; revised March 12, 2018.

Ziming Wang is with the University of Chinese Academy of Sciences, China (e-mail: wangzimingsq88@qq.com). therapy. However, these methods were not managed systematically, effectively or enough. The relapsing rate was very high, although the cure rate of depression was less than $10 \%$ at domestic in recent years. Owing to the choice and the application of treatment being not good or poor, depression genes remaining at the research stage, quite a few genes having not been found, it was normal that depression was treated poorly or not to be cured. So the therapy for depression with four kinds of severities (mild, moderate, severe and extremely severe) had been studied on the basis of summarizing the research results of depression worldwide.

Change management and risk management and control for therapy were implemented effectively through the analysis of four kinds of severities symptoms, pathological analysis, diagnosis and therapy, scale analysis and testing and manipulating. In combination with the actual situation of patients, depression was cured effectively. The pain of patients was reduced and the pressure and burden of family and society were got rid of. Depression therapy was combined with treatment of other diseases and protection of body organs.

Although more than 20 depression genes have been found globally, but a considerable part of them still were not found. Genome-editing technology has not be applied in the clinical therapy in China, and it was limited for the treatment of leukemia and bone cancer in America. Genes of depression were individually or partly, so the process of treatment can be treated as "trinity" structure. That was to maintain the stability of the trinity structure of "depression, therapy and recovery". Depression was recurred every two to five years. The therapeutic process of depression owing to the same etiology can be repeated constantly. So depression therapy was a process of continuous improvement and consolidation of curative effects.

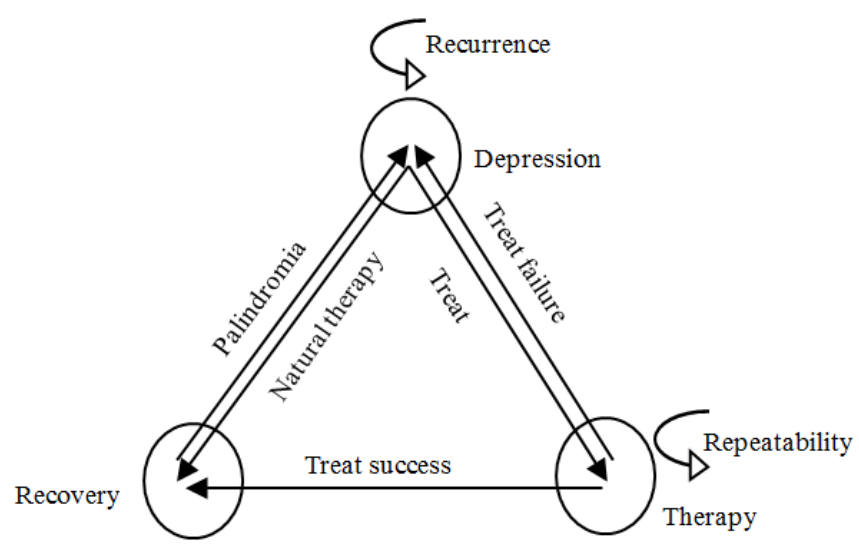

Fig. 1. Schematic diagram of trinity structure for depression therapy. 


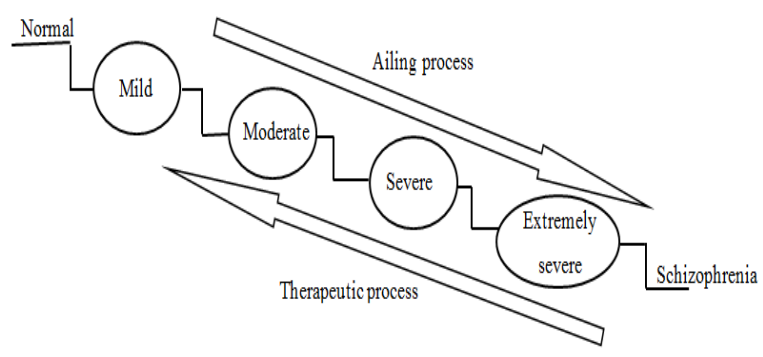

Fig. 2. Flow chart of therapy for depression with four kinds of severities.

\section{B. Literature Review}

Depression was the result of dopamine concentration disorders in human body. It was mainly relied on psychological counseling, drugs and brain stimulation therapy and so forth[3]. The major affecting factors for depression were genes and environment[4]. Other affecting factors for depression were also included. Exercise were enough (such as abdominal obesity and dyslipidemia), and curative effects of moderate exercise were remarkable[5, 6]. It was biggest affected by social environment, especially in the high risk occupation, such as female students in school of medicine[7]. Depressive behaviors can be affected by intestinal flora changes of diet and diet relation[8, 9]. It may be too high to decrease non-oxidative pressure and non-oxidation behaviors. it was directly affected by stress and irritability. And these result in appearing in motivation deficits, behavioral abnormalities and lack of pleasure [10-12]. Sleep quality was poor. And sleep time was not enough [13]. There exists smoking addictive behaviors, but the expected improvement in happiness was not achieved by smoking [14]. Signaling pathway of ERK-CREB was damaged [15].

Depression can be clinically treated with other diseases, such as hypertensive diseases [16]. It was in high risk by depression therapy including angiocardiopathy, dementia, coronary diseases, apoplexia, cancer, committing suicide and so on [17]-[19]. An enhancement of 5-HT-mediated neurotransmission may underlie the therapeutic effect of most antidepressant treatments [20]. It was treated by fluoxetine hydrochloride [15]. At present, there was confusion for medical community among related kinds of severity of depression. And it was lack of antidepressant drugs selection for related kinds of severities [21].

\section{THERAPEUTIC MODELING FRAMEWORK}

\section{A. Symptom Counseling and Diagnosis}

The common symptoms of depression were as follows: sadness, disappointment, low self-esteem, inferiority, guilt conscience, hesitation, anxiety, losing interest in life, loss of motivation, poor self-image, appetite changes, sleep change, loss of libido, hypochondriasis, suicidal impulse and emotional upset.

The common diagnostic method for depression contained: According to the patients' symptoms, psychological observation, consultation and diagnosis of doctors, nuclear magnetic resonance detection, psychological questionnaire test, analysis of physiological and chemical indexes, CPS psychometric instrument, PGA99 or PGA2000 psychometric instrument and physio psychological tester. Of course, medical standards should were conformed including ISO 14971: 2007, GB 9706, YY 0505 etc.

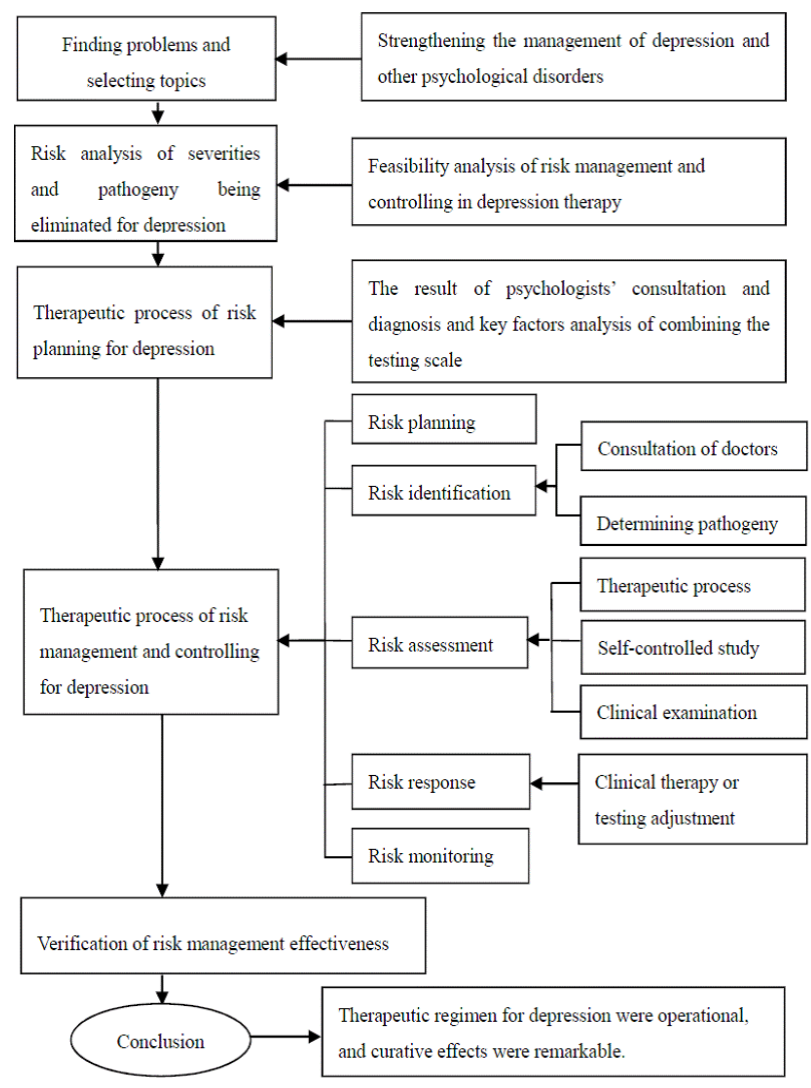

Fig. 3. Mind map of risk management for depression therapy

\section{B. Determination of Therapeutic Process and Course}

Reasonable therapeutic process of depression can be carried out as follows.

Personal psychological control, catharsis. $\rightarrow$ If the process cannot be completed, the individual should immediately be sent to normal hospital. $\rightarrow$ The doctor confirmed the disease, and patients or their families understand the disease. $\rightarrow$ The patients' cognition needed to be improved. And let them actively cooperate with the treatment. $\rightarrow$ Judging from the symptoms and severities of the patients and doctors consultation, it was determined whether or not clinical therapy needed. $\rightarrow$ If it was severe, it was to determine the course of therapy, hospitalize for observation and contrast curative effects in each stage. If it was not severe, antidepressant drugs selection and the therapeutic regimen was made. $\rightarrow$ After the consolidation period, the patients need to continue to follow the medication until the course was completed. After the patients' recovery, if the symptoms appeared, the patient was cured immediately until symptoms disappeared.

The course of therapy with four kinds of severities was determined by the patient. The score of the condition and curative effects was set including the followings: the mild being for 1 weeks, the moderate being for 2 weeks, the severe being for 4 weeks and the extremely severe being for 6 weeks. When the patient was treated, it was the best to need to be taken care of. When in clinical therapy, it depended on the severity of the patient's condition, medical level, individual physical quality, psychological quality, the 
patient's condition and other actual situations. The patient was targeted with an appropriate therapy and actual effects were paid attention to. The therapeutic effect of depression was maintained and consolidated. It was paid attention to including practicality, easy to being used, economy and efficiency. The therapeutic data were fully grasped at each stage. Thus the patient could be cured. Four kinds of severities of special groups were determined by actual situations including heart disease, infectious diseases, cancer, frail constitution, psychic trauma, the old, the young and the disabled concretely.

\section{Pathological Analysis}

Pathological analysis was mainly affected by genovariation of depression including genetic inheritance, depressive personality, social environment (interpersonal relationship, work fatigue and stress, family contradiction and marriage problems), emotional and mental control. The methods of pathological analysis were as follows.

1) Let the patient and his family speak out forwardly.

2) Let the patient speak out through psychological counseling and the doctor interrogation.

3) It was detected by medical instruments.

4) It was through the psychological questionnaire.
5) It was through the observation of symptoms.

6) It was identified through family constellations.

\section{Clinical Therapy}

The pathogeny of depression should be measurable. The following 39 factors of depression were "Genovariation", "Genetic inheritance", "Ability to adapt to social environment", "Social environment", "Working and living environment", "Mental irritability/ sudden event", "Interpersonal relationship", "Talk and communication", "Sleep quality", "Last sleep time", "Activity of brain signaling system (ERK-CREB)", "Pathway of cAMP signal damage", "Mental fatigue", "Mental stress", "Mental status", "Current level of depression", "Psychological quality", "Emotion and feeling", "Mentality", "Character", "Ordinariness", "Evil, crime and suicide", "Family", "Marriage", "Cognition", "Habit and custom", "Diet", "Drinking and smoking", "Sexual pleasure", "Sense of professional achievement", "Opportunity choice", "Wealth", "Culture", "Body refreshing", "Constitution", "Strengthening the bone", "Puzzle game", "Sunshine duration" and "Changing season".

TABLE I: TESTING AND MANIPULATING SCALE OF DEPRESSION (WZM)

\begin{tabular}{|c|c|c|c|c|c|}
\hline \multirow{2}{*}{ Pathogeny } & \multicolumn{3}{|c|}{ Before improvement } & \multicolumn{2}{|l|}{ After improvement } \\
\hline & Level & Existential question & Suggestion & Measure & Level \\
\hline Genovariation & 3 & $\begin{array}{l}\text { 1. The influence of social environment, } \\
\text { educational environment and home } \\
\text { environment involved. } \\
\text { 2. Some or some combinations of } \\
\text { DNA were expected (More than } 20 \\
\text { were found now). } \\
\text { 3. A small proportion of genes for } \\
\text { depression copying errors and } \\
\text { escaping DNA repair, the stable DNA } \\
\text { repair system is destroyed. }\end{array}$ & $\begin{array}{l}\text { If the patient was with } \\
\text { history of inheritance, } \\
\text { all the influencing } \\
\text { factors in the scale } \\
\text { should be analyzed and } \\
\text { controlled. And it was } \\
\text { to avoiding the patient } \\
\text { married. }\end{array}$ & $\begin{array}{l}\text { 1. The marriage and birth among the } \\
\text { depressive patients were put an end to. } \\
2 \text {. Taking antidepressant drugs. } \\
\text { 3. The influence of different race, sex } \\
\text { and the etiology. } \\
\text { 4. Blood samples were collected from } \\
\text { the same patient } \rightarrow \text { Genes } \\
\text { sequencing } \rightarrow \text { Genome wide } \\
\text { association analysis } \rightarrow \text { Discovery of } \\
\text { alleles of genes. }\end{array}$ & 1 \\
\hline $\begin{array}{l}\text { Genetic } \\
\text { inheritance }\end{array}$ & 2 & $\begin{array}{l}\text { It was in accordance with the actual } \\
\text { situation }\end{array}$ & $\begin{array}{l}\text { If the patient was with } \\
\text { history of inheritance, all } \\
\text { the influencing factors in } \\
\text { the scale should be } \\
\text { analyzed and controlled. } \\
\text { And it was to avoiding } \\
\text { the patient married. }\end{array}$ & $\begin{array}{l}\text { 1. The marriage and birth among the } \\
\text { depressive patients were put an end to. } \\
2 \text {. Taking antidepressant drugs. } \\
\text { 3. The influence of different race, sex } \\
\text { and the etiology. } \\
\text { 4. Blood samples were collected from } \\
\text { the same patient } \rightarrow \text { Genes } \\
\text { sequencing } \rightarrow \text { Genome wide association } \\
\text { analysis } \rightarrow \text { Discovery of alleles of genes. }\end{array}$ & 1 \\
\hline $\begin{array}{c}\text { Factor } 3 \text { to } \\
39\end{array}$ & Score: $0-4$ & $\cdots$ & $\cdots$ & $\ldots$ & Score: $0-4$ \\
\hline
\end{tabular}

The following 16 factors of physiological and chemical indexes for depression were "Genovariation or Genetic inheritance", "Dopamine concentration", "5-HT concentration", "Norepinephrine", "P substance", "Enkephalin", "Trinity Structure of the brain", "Activity of brain signaling system (ERK-CREB)", "Pathway of cAMP signal damage", "Thyroid hormone", "Estrin", "Glucocorticoid", “Cortisol level", "Proinflammatory factors", "Bacteroides content" and "Firmicutes content".

TABLE II: PhySIOLOGICAL AND CHEMICAL ANALYSIS OF ETIOLOGY FOR DEPRESSION

\begin{tabular}{ccccc}
\hline \hline $\begin{array}{c}\text { Physiological and } \\
\text { chemical index }\end{array}$ & $\begin{array}{c}\text { Before } \\
\text { improvement }\end{array}$ & Measure & Effect & $\begin{array}{c}\text { After } \\
\text { improvement }\end{array}$ \\
\hline Factor 1 to 16 & Score: 0-4 & $\ldots$ & $\ldots$ & Score: 0-4 \\
\hline \hline
\end{tabular}

\section{E. Risk Management Model of Therapy}

\section{THERAPY CASE STUDY}

One patient was taken as an example.

\section{A. Impact of depression}

It was affected by depression including work and learning efficiency, life and the individual.

1) Affecting the efficiency of work and study: low work and learning efficiency, initiative, enthusiasm etc.

2) Affecting life: family, habit, interest, feelings, emotion etc.

3) Affecting the individual: suicide, concentration, low psychological pressure, sexual dysfunction, mental deterioration, volitional dysfunction, being in a bad mood and decreasing interest, retardation or disturbance of thought, poor sleep, inferiority, condemning himself and actual sin, physical discomfort, poor diet, cognitive impairment, 
somatoform disorders and impaired.

\section{B. Process of depression therapy}

Common antidepressants mainly were divided into four categories including tricyclic antidepressants, monoamine oxidase inhibitors, selective 5-HT reuptake inhibitors and new antidepressants of other neurotransmitter mechanisms.

TABLE III: ANALYSIS OF ANTIDEPRESSANT DRUGS WITH FOUR KINDS OF SEVERITIES

\begin{tabular}{|c|c|c|c|}
\hline Severity & Symptom & Therapeutic drug and psychological manipulating & Matters need attention \\
\hline $\begin{array}{l}\text { Extremely } \\
\text { serve }\end{array}$ & $\begin{array}{l}\text { Verging on schizophrenia, showing a } \\
\text { serious social disorder, social } \\
\text { withdrawal, emotional disorder, } \\
\text { cognitive ambiguity, inferiority or } \\
\text { arrogance, accompanying mania, } \\
\text { hallucinations, delusions, hostility } \\
\text { and other symptoms and having a } \\
\text { serious suicide attempt. }\end{array}$ & $\begin{array}{l}\text { 1. In clinical therapy, medicines were mainly } \\
\text { taken including risperdal, SSRIs (fluoxetine, } \\
\text { paroxetine, sertraline, fluvoxamine, citalopram } \\
\text { and escitalopram) etc. } \\
\text { 2. Adjuvant psychological manipulating: } \\
\text { changing the character, changing and adapting to } \\
\text { social environment, controlling emotion, feeling } \\
\text { and mentality and changing living habits. }\end{array}$ & \multirow{3}{*}{$\begin{array}{l}\text { 1. Antidepressant } \\
\text { medication should be } \\
\text { prescribed in accordance } \\
\text { with the medical } \\
\text { examination. } \\
2 \text {. Applying medicine } \\
\text { according to indications. } \\
3 \text {. Whether or not there } \\
\text { were side effects or the } \\
\text { requirement of taboo. } \\
\text { 4. Selection of } \\
\text { antidepressant drugs } \\
\text { should be taken into } \\
\text { account including } \\
\text { other diseases (Other } \\
\text { psychological diseases, } \\
\text { cancer, cardiovascular } \\
\text { diseases, suicide and so } \\
\text { on) therapy and }\end{array}$} \\
\hline Serve & $\begin{array}{l}\text { Showing social competence disorder, } \\
\text { social withdrawal, somatic } \\
\text { discomfort, loss of appetite, cognitive } \\
\text { ambiguity, being pessimistic and } \\
\text { worldweary, despair, hallucination, } \\
\text { delusion, inferiority, conceit, } \\
\text { dysfunction and having a serious } \\
\text { suicide attempt. }\end{array}$ & $\begin{array}{l}\text { 1. Traditional Chinese medicine and Western } \\
\text { Medicine were mainly taken including risperdal, } \\
\text { vilazodone, SSRIs (fluoxetine, paroxetine, } \\
\text { sertraline, fluvoxamine, citalopram and } \\
\text { escitalopram) etc. } \\
\text { 2. Adjuvant psychological manipulating: } \\
\text { changing the character, changing and adapting to } \\
\text { social environment, controlling emotion, feeling } \\
\text { and mentality and changing bad living habits. }\end{array}$ & \\
\hline Moderate & $\begin{array}{l}\text { Showing social competence disorder, } \\
\text { psychomotor block, functional brain } \\
\text { block, weak cognition, lack of } \\
\text { interest, being down in spirits, loss of } \\
\text { energy, obvious anxiety, radical } \\
\text { behaviors and the trend of suicide. }\end{array}$ & $\begin{array}{l}\text { 1. Traditional Chinese medicine and Western } \\
\text { medicine were mainly taken including morinda } \\
\text { officinalis oligose capsule, Chinese herbal } \\
\text { medicine shu-gan-jie-yu, neurostan, SSRIs } \\
\text { (fluoxetine, paroxetine, sertraline, fluvoxamine, } \\
\text { citalopram and escitalopram) etc. } \\
\text { 2. Adjuvant psychological manipulating: } \\
\text { changing the character, changing and adapting to } \\
\text { social environment, controlling emotion, feeling } \\
\text { and mentality and changing bad living habits. }\end{array}$ & \\
\hline Mild & $\begin{array}{l}\text { Unwilling to socialize with others, } \\
\text { being in low mood, feeling } \\
\text { constrained, lack of interest, being } \\
\text { pessimistic about the future, being } \\
\text { shame and guilt, inattention, } \\
\text { cognitive decline, low self-esteem } \\
\text { and confidence, exaggerating your } \\
\text { own shortcomings and mistakes, } \\
\text { self-accusation and actual sin, action } \\
\text { hysteresis, passivity and dependence. }\end{array}$ & $\begin{array}{l}\text { 1. Psychological manipulating was mainly relied } \\
\text { on: changing the character, changing and } \\
\text { adapting to social environment, controlling } \\
\text { emotion, feeling and mentality and changing bad } \\
\text { living habits. } \\
\text { 2. Adjuvant Chinese medicine and Western } \\
\text { medicine: neurostan, SSRIs (fluoxetine, } \\
\text { paroxetine, sertraline, fluvoxamine, citalopram } \\
\text { and escitalopram) etc. }\end{array}$ & $\begin{array}{l}\text { protection of functional } \\
\text { organs of human body. }\end{array}$ \\
\hline
\end{tabular}

TABLE IV: APPLICATION AND ANALYSIS OF NATURAL THERAPY FOR DEPRESSION

\begin{tabular}{|c|c|c|c|}
\hline Item & $\begin{array}{l}\text { Main therapeutic measure } \\
\end{array}$ & Advantage & Disadvantage \\
\hline $\begin{array}{l}\text { Music } \\
\text { intracavitary }\end{array}$ & $\begin{array}{l}\text { Playing quiet and elegant songs, such as wave of Rhine river, the miracle of } \\
\text { listening, health relaxation, pressure relaxation therapy, yoga practice, emotional } \\
\text { releasing, flowers sleeping below the lake, sleep peacefully etc. }\end{array}$ & \multirow{7}{*}{$\begin{array}{l}\text { Relieving } \\
\text { depression } \\
\text { to the } \\
\text { utmost } \\
\text { extend }\end{array}$} & \multirow{7}{*}{$\begin{array}{l}\text { Being } \\
\text { difficult to } \\
\text { cure patients } \\
\text { thoroughly }\end{array}$} \\
\hline $\begin{array}{l}\text { Emotional } \\
\text { therapy }\end{array}$ & $\begin{array}{l}\text { Listening to emotional music, changing environment, expressing his discontent, } \\
\text { finding solutions to problems and improving unhealthy social relations. }\end{array}$ & & \\
\hline Aromatherapy & $\begin{array}{l}\text { Putting flowers and plants in house, change air regularly, cleaning the room } \\
\text { regularly, and cleaning clothes. }\end{array}$ & & \\
\hline $\begin{array}{l}\text { Alimentary } \\
\text { therapeutic }\end{array}$ & $\begin{array}{l}\text { Supplementing the missing elements of the body, such as vitamin B1, B2, C and } \\
\text { paying attention to diet balance. }\end{array}$ & & \\
\hline Cinesiatrics & Strengthening outdoor sports and exercise. & & \\
\hline $\begin{array}{l}\text { Release of } \\
\text { pressure }\end{array}$ & $\begin{array}{l}\text { Reducing the pressure source, resolving disputes, having a rest, releasing pressure } \\
\text { regularly, eating more vegetables and fruits for stress relieving, using language } \\
\text { and imagination to relieve stress and listening to decompression music. }\end{array}$ & & \\
\hline $\begin{array}{l}\text { Pleasant } \\
\text { sensation }\end{array}$ & $\begin{array}{l}\text { Working and living happily, family and marriage should being happy, playing } \\
\text { puzzle games and improving sexual pleasure. }\end{array}$ & & \\
\hline
\end{tabular}

\section{Curative Effect}

TABLE V: COMPARISON OF CURATIVE EFFECT IN EACH STAGE

\begin{tabular}{cll}
\hline \hline Therapeutic stage & \multicolumn{1}{c}{ Main therapeutic measures } & \multicolumn{1}{c}{ Curative effect } \\
\hline \multirow{2}{*}{ Pretherapy } & $\begin{array}{l}\text { 1. The medicine of piracetam was fully taken. } \\
\text { 2. Mental regulation was carried out by NaiKan } \\
\text { cognitive therapy, Morita therapy, emotional therapy, }\end{array}$ & $\begin{array}{l}\text { Social impairments were not seriously } \\
\text { acceptable. Social withdrawal was also } \\
\text { serious. Mentality and emotions were out }\end{array}$ \\
\hline
\end{tabular}


of control. Symptoms of inferiority, arrogance, insomnia, mania, compulsion, hallucination, delusion, hostility and fear disappeared. There was a serious suicide attempt.

\begin{tabular}{|c|c|c|c|}
\hline $\begin{array}{l}\text { The first therapeutic } \\
\text { process being } \\
\text { completed }\end{array}$ & $\begin{array}{l}\text { 1. The main medicine was taken including risperidone, } \\
\text { alprazolam, chlorpromazine and neurostan. } \\
\text { 2. Adjuvant medicine was taken including creatinine, } \\
\text { propranolol, vitamin C, vitamin B1. } \\
\text { 3. Psychological manipulation measures were taken } \\
\text { including psychological counseling, sleep therapy, } \\
\text { music therapy, static magnetic therapy, mental and } \\
\text { emotional control, cognitive therapy and various } \\
\text { psychological scales. }\end{array}$ & $\begin{array}{l}\text { Social impairments, mental, emotional and } \\
\text { cognitive abilities were acceptable. The } \\
\text { symptom of delusions, mania, compulsion, } \\
\text { fear and suicidal attempt disappeared. But } \\
\text { the possibility of relapsing for depression } \\
\text { was great. }\end{array}$ & Good \\
\hline $\begin{array}{l}\text { The second } \\
\text { therapeutic process } \\
\text { being completed }\end{array}$ & $\begin{array}{l}\text { 1. The main medicine was taken including visteon, } \\
\text { fluoxetine. } \\
\text { 2. The adjuvant medicine was taken including } \\
\text { creatinine, propranolol, vitamin C, vitamin B1. } \\
\text { 3. Psychological manipulation measures were taken } \\
\text { including psychological counseling, Berns emotional } \\
\text { therapy, Becks cognitive therapy, Morita therapy, } \\
\text { Harvard positive psychology, music therapy, natural } \\
\text { therapy. } \\
\text { 4. It was adopted including depression scale of testing } \\
\text { and manipulating (WZM), Stanford sleepiness scale, } \\
\text { analysis of physical and chemical indexes of } \\
\text { depression. } \\
\text { 5. It was adopted including risk management and } \\
\text { control for depression, analysis of genovariation, } \\
\text { social environment and irritability avoidance, } \\
\text { maintaining therapeutic trinity balance. }\end{array}$ & $\begin{array}{l}\text { Sociability was normal. Mentality and } \\
\text { emotions control were better. Cognitive } \\
\text { ability was strong. The possibility of } \\
\text { relapsing of delusion and depression } \\
\text { disappeared. Psychology was applied to } \\
\text { solve problems in work and life. Others' } \\
\text { emotions were able to be appeased. }\end{array}$ & Better \\
\hline $\begin{array}{l}\text { Consolidation } \\
\text { period }\end{array}$ & $\begin{array}{l}\text { 1. It was adopted including depression scale of testing } \\
\text { and manipulating (WZM), Stanford sleepiness scale, } \\
\text { risk management and control for depression, analysis } \\
\text { of genovariation, social environment and irritability } \\
\text { avoidance, maintaining therapeutic trinity balance and } \\
\text { adopting natural therapy. } \\
\text { 2. It was on the integrated management for } \\
\text { psychology and in psychological consultant training. }\end{array}$ & $\begin{array}{l}\text { Sociability, emotions, and mentality being } \\
\text { normal, stable control of relapse of } \\
\text { depression, cohesion and collocation in all } \\
\text { aspects of psychology effectively. }\end{array}$ & Better \\
\hline After being cured & $\begin{array}{l}\text { 1. It was on the integrated management for } \\
\text { psychology. } \\
\text { 2. Trinity balance of therapy was maintained. Testing } \\
\text { and manipulating scale of depression (WZM) was } \\
\text { adopted. Genovariation was analyzed. }\end{array}$ & $\begin{array}{l}\text { Manipulating emotions and mentality, } \\
\text { applying natural therapy flexibly and risk } \\
\text { management and control of the uncertainty } \\
\text { of genovariation and genetic inheritance for } \\
\text { depression. }\end{array}$ & Better \\
\hline
\end{tabular}

\section{DISCUSSION}

There were four generations of gene sequencing technology. And detection technology was also maturing. The inevitable trend of future development was of low cost,

the highest success rate of sequencing, easy operation and intellectualization. CRISPR-Cas9, TALEN, ZFN and TtAgo were the common Genome-editing technologies.

\begin{tabular}{cccc} 
TABLE VI: CORREATION ANALYSIS OF GENE FOR DEPRESSION & Source \\
\hline \hline Gene name & Editability & Significance & Depression \\
\hline MKP-1[22] & Yes & Important & Depression \\
\hline Tryptophan hydroxylase-2[23] & Yes & Important & Depression \\
\hline VGF[24] & Yes & Important & Depression/ Schizophrenia \\
\hline Rhe C-terminal domain of DISC1[25] & Yes & Important & Depression \\
\hline One near the SIRT1 gene[27] & Yes & Important & Depression \\
\hline One in an intron of the LHPP gene[27] & Yes & Important & Depression \\
\hline BDNF mRNA[28] & Yes & Important & Depression \\
\hline One key molecular of $\beta$ CaMKII[29] & Yes & Important & Depression \\
\hline T102C of 5-HT2A receptor gene[30] & Yes & Important & Depression \\
\hline SLC6A15[31] & Yes & Important & Depression \\
\hline Mitochondrial transcription factor A, TFAM[32] & Yes & Important & Depression \\
\hline DARPP-32(the T-allele)[33] & Yes & Important & Anger \\
\hline SNAP25[34] & Important & Schizophrenia \\
\hline CMYA5[34] & Yes & Important & Important \\
\hline CDH7[34] & Yes & Important & Schizophrenia \\
\hline MAOA[35] & Yes & Important & Violence \\
\hline
\end{tabular}




\begin{tabular}{ccll}
\hline CDK6[32] & Yes & Important & Cancer \\
\hline MEK[36] & Yes & Important & Cancer \\
\hline Short allele of 5-HTTLPR (SERT gene) [37] & Yes & Important & Anxiety \\
\hline Unknown gene estimated (21-50) & Unknown & Unknown & Unknown \\
\hline \hline
\end{tabular}

Depression should be treated effectively as follows.

1) It was to cope with genovariation, genetic inheritance and genome-editing technology (influencing accounted for $60 \%$ ).

2) It was to change environment including social, interpersonal, family and educational environment (influencing accounted for $30 \%$ ).

3) Applying testing and manipulating scale of depression (WZM) , maintaining trinity balance of therapy and strengthening the training of natural therapy.

\section{CONCLUSION}

The following five aspects were concluded in the results of this study.

1) It was developed well for testing and manipulating scale of depression (WZM). And physiological and chemical analysis of etiology for depression was also referred in clinical therapy.

2) It was analyzed for depression with four kinds of severities, symptoms and commonly used drugs.

3) Risk management and control were implemented in the therapeutic process of depression.

4) It was expounded for the common therapeutic measures of depression natural therapy.

5) It was discussed including gene analysis of depression, curing depression effectively, applying risk management and control effectively and responding to genetic variation effectively.

\section{ACKNOWLEDGEMENT}

I would like to acknowledge the contribution of Qingsheng $\mathrm{Bi}$ (Changchun Institute of Technology, School of Energy and Power Engineering) who provided me with the requirements of testing and data. In addition, I was grateful to our teacher Wenguo Yang (University of Chinese Academy of Sciences, School of Mathematical Sciences) for teaching a course in risk management and providing relevant literature.

\section{REFERENCES}

[1] S. Chen, B. Mulgrew, and P. M. Grant, "A clustering technique for digital communications channel equalization using radial basis function networks," IEEE Trans. on Neural Networks, vol. 4, pp. 570-578, July 1993.

[2] Zhongcun Jing, Wanghong Shi, Easy to Say Goodbye to Depression: Morita Health Regimen, Xi'an, CN: 2008, pp. 45-47.

[3] World Health Organization, Depression and Other Common Mental Disorders: Global Health Estimates.

[4] K. M. Tye, J. J. Mirzabekov, M. R. Warden, E. A. Ferenczi, H. C. Tsai, J. Finkelstein, S. Y. Kim, A. Adhikari, K. R. Thompson, A. S. Andalman, L. A. Gunaydin, I. B. Witten, and K. Deisseroth, "Dopamine neurons modulate neural encoding and expression of depression-related behavior," Nature, vol. 493, no. 7433, pp. 537-541, Jan. 2013.

[5] M. R. Munafò, C. Durrant, G. Lewis, and J. Flint, "Genex environment interactions at the serotonin transporter locus," Biological Psychiatry, vol. 65, no. 3, pp. 211-219, Feb. 2009.

[6] F. B. Schuch, D. Vancampfort, J. Richards, S. Rosenbaum, P. B. Ward, and B. Stubbs, "Exercise as a treatment for depression: A meta-analysis adjusting for publication bias," Physioscience, vol. 12, no. 3, pp. 122-123, Jun. 2016.

[7] P. B. Wjh, M. Yuri, L. Femke, and V. Nicole, "Understanding the somatic consequences of depression: biological mechanisms and the role of depression symptom profile," BMC Medicine, vol. 11, no. 31, pp. 129-142, May 2013.

[8] S. Iqbal, S. Gupta, and E. Venkatarao, "Stress, anxiety and depression among medical undergraduate students \& their socio-demographic correlates," Scientific Research, vol. 5, no. 4, pp. 260-268, Nov. 2015.

[9] R. A. Luna, and J. A Foster, "Gut brain axis: diet microbiota interactions and implications for modulation of anxiety and depression," Current Opinion in Biotechnology, vol. 32, no. 32, pp. 35-41, Apr. 2015.

[10] S. Liang, T. Wang, X. Hu, J. Luo, W. Li, X. Wu, Y. Duan, and F. Jin "Administration of lactobacillus helveticus NS8 improves behavioral, cognitive, and biochemical aberrations caused by chronic restraint stress," Neuroscience, vol. 310, no. 21, pp. 561-577, Dec. 2015.

[11] C. N. Black, M. Bot, P. G. Scheffer, P. Cuijpers, and W. J. H. B. Penninx, "Is depression associated with increase doxidative stress? A systematic review and meta-analysis," Psychoneuroendocrinology, vol. 51, no. 5, pp. 164-175, Jan. 2015.

[12] B. R. Miller and R. Hen, "The current state of the neurogenic theory of depression, and anxiety," Current Opinion in Neurobiology, vol. 30, pp. 51-58, Feb. 2015

[13] S. Ramirez, X. Liu, C. J. MacDonald, A. Moffa, J. Zhou, R. L. Redondo, and S. Tonegawa, "Activating positive memory engrams suppresses depression-like behavior," Nature, vol. 522, no. 7556, pp. 335-339, Jun. 2015.

[14] A. A. Prather, N. Vogelzangs, and B. W. J. H. Penninx, "Sleep duration, insomnia, and markers of systemic inflammation: Results from the Netherlands Study of Depression and Anxiety (NESDA)," Journal of Psychiatric Research, 2015.

[15] A. M. Leventhal and M. J. Zvolensky, "Anxiety, depression, and cigarette smoking: a transdiagnostic vulnerability framework to understanding emotion-smoking comorbidity," Psychological Bulletin, vol. 141, no. 1, pp. 176-212, Jan. 2015.

[16] X. Qi, W. Lin, J. Li, Li H, Wang W, Wang D, and Sun M, "Fluoxetine increases the activity of the ERK-CREB signal system and alleviates the depressive-like behavior in rats exposed to chronic forced swim stress", Neurobiology of Disease, vol. 31, no. 2, pp. 278-285, Aug. 2008.

[17] Yuling $\mathrm{Hu}$, "The comparison of different methods to treat with the patients with depression accompanied by hypertension," Sichuan Medical Journal, vol. 33, no. 3, pp. 515-517, Jun. 2012

[18] A. Seldenrijk, N. Vogelzangs, N. M. Batelaan, I. Wieman, D. J. V. Schaik, and B. J. Penninx, "Depression, anxiety and 6-year risk of cardiovascular disease," Journal of Psychosomatic Research, vol. 78, no. 2, pp. 123-129, Feb. 2015.

[19] W. D. Taylor, H. J. Aizenstein, and G. S. Alexopoulos, "The vascular depression hypothesis: Mechanisms linking vascular disease with depression," Molecular Psychiatry, vol. 18, no. 9, pp. 963-974, Sep. 2013.

[20] C. A. Hall and C. F. R. Iii, "Late-life depression in the primary care setting: Challenges, collaborative care, and prevention," Maturitas, vol. 79, no. 2, pp. 147-152, Oct. 2014.

[21] P. Blier and M. C. De, "Current advances and trends in the treatment of depression," Trends in Pharmacological Sciences, vol. 15, no. 7, pp. 220-226, Jul. 1994.

[22] E. I. Fried and R. M. Nesse, "Depression sum-scores don't add up: why analyzing specific depression symptoms is essential," Bmc Medicine, vol. 13, no. 1, pp. 1-11, Apr. 2015.

[23] V. Duric, M. Banasr, P. Licznerski, H. D. Schmidt, C. A. Stockmeier, A. A. Simen, S. S. Newton, and R. S. Duman, "A negative regulator of MAP kinase causes depressive behavior," Nature Medicine, vol. 16, no. 11, pp. 1328-1332, Nov. 2010.

[24] X Zhang and M. G. Caron, "Tryptophan hydroxylase-2 controls brain serotonin synthesis," Science, vol. 305, no. 5681, pp. 217-217, Jul. 2004.

[25] J. G. Hunsberger, S. S. Newton, A. H. Bennett, C. H. Duman, D. S Russell, S. R. Salton, and R. S. Duman, "Antidepressant actions of the exercise-regulated gene VGF," Nature Medicine, vol. 13, no. 12, pp. 1476-1482, Dec. 2007. 
[26] S. D. Greenhill, K. Juczewski, A. M. D. Haan, G. Seaton, K. Fox, and N. R. Hardingham, "Adult cortical plasticity depends on an early postnatal critical period," Science, vol. 349, no. 6246, pp. 424-427, Jul. 2015.

[27] D. C. Glahn, J. E. Curran, A. M. Winkler, M. A. Carless, J. W. K. Jr, J. C. Charlesworth, M. P. Johnson, H. H. Göring, S. A. Cole, T. D. Dyer, E. K. Moses, R. L. Olvera, P. Kochunov, Duggirala R, Fox PT, Almasy L, and Blangero J, "High Dimensional Endophenotype Ranking in the Search for Major Depression Risk Genes”, Biological Psychiatry, vol. 71, no. 1, pp. 6-14, Jan. 2012.

[28] C Consortium, "Sparse whole-genome sequencing identifies two loci for major depressive disorder," Nature, vol. 523, no. 7562, pp 588-591, Jul. 2015.

[29] S. Murakami, H. Imbe, Y. Morikawa, C. Kubo, and E. Senba, "Chronic stress, as well as acute stress, reduces BDNF mRNA expression in the rat hippocampus but less robustly," Neuroscience Research, vol. 53, no. 2, pp. 129-139, Oct. 2015.

[30] K. Li, T. Zhou, L. J. Liao, Z. F. Yang, C. Wong, F. Henn, R. Malinow,

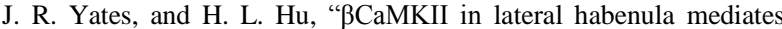
core symptoms of depression," Science, vol. 341, no. 6149, pp. 1016-1020, Aug. 2013.

[31] Y. Tang, J. Zhang, L. Qing, and H. Y. Liu, "A preliminary fMRI study on serotonin 2A ( HT2A ) receptor gene polymorphism and subregions of frontal lobes in depressed," Journal of Clinical Psychiatry, vol. 21, no. 5, pp. 291-294, Oct. 2011.

[32] X. Cao, L. P. Li, Q. Wang, Q. Wu, H. H. Hu, M. Zhang, Y. Y. Fang, J. Zhang, S. J. Li, W. C. Xiong, H. C. Yan, Y. B. Gao, J. H. Liu, X.W. Li, L. R. Sun, Y. N. Zeng, X. H. Zhu, and T. M. Gao, "Astrocyte-derived ATP modulates depressive-like behaviors," Nature Medicine, vol. 19, no. 1, pp. 773-777, May 2013.

[33] N. Cai, Y. H. Li, S. Chang, J. Q. Liang, C. Y. Lin, X. F. Zhang, L. Liang, J. C. Hu, W. Chan, K. S. Kendler, T. Malinauskas, G. J. Huang,
Q. B. Li, R. Mott, and J. Flint, "Genetic control over mtDNA and its relationship to major depressive disorder," Current Biology $\mathrm{Cb}$, vol. 25, no. 24, pp. 3170-3177, Dec. 2015.

[34] M. Reuter, B. Weber, C. J. Fiebach, C. Elger, and C. Montag, "The biological basis of anger: Associations with the gene coding for DARPP-32 (PPP1R1B) and with amygdala volume," Behavioural Brain Research, vol. 202, no. 7, pp. 179-183, Sep. 2009.

[35] Q. Z. Wang, "Association analysis of SNAP25, CMYA5, ZNF804A and CDH7 genes with schizophrenia and major depression," Shanghai Jiao Tong University, pp. 14-14, 2014.

[36] C. Cong, C. Guanghui, W. Meiping, C. Yanmiao, and Z. Wenxin, "Association between MAOA gene and depression," Advances in Psychological Science, vol. 22, no. 12, pp. 1899-1910, Jan. 2014

[37] Y. Y. Hu, Y. R. Fang, S. Y. Yu, D. X. Wang, and W. Hong, "Association between MEK gene polymorphisms and depression," Journal of Shanghai Jiaotong University, vol. 30, no. 6, pp. 616-619, Dec. 2010

[38] L. Pezawas, A M. Lindenberg, E. M. Drabant, B. A. Verchinski, K. E. Munoz, B. S. Kolachana, M. F. Egan, V. S. Mattay, A. R. Hariri, and D. R. Weinberger, "5-HTTLPR polymorphism impacts human cingulate-amygdala interactions: A genetic susceptibility mechanism for depression," Nature Neuroscience, vol. 8, no. 6, pp. 828-834, Jun. 2005

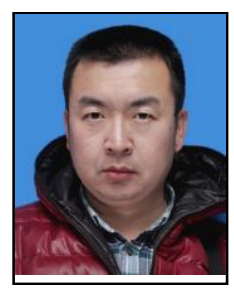

Ziming Wang was born in 1982, graduated from University of Chinese Academy of Sciences in 2017 and majored in project management at present (master degree, Beijing in China). 